\title{
Effect of Henna (Lawsonia inermis) extract on the immunity and survival of common carp, Cyprinus carpio infected with Aeromonas hydrophila
}

\author{
Siyavash Soltanian • Mohammad Saeid Fereidouni
}

Received: 30 December 2015/Accepted: 3 August 2016/Published online: 16 August 2016

(C) The Author(s) 2016. This article is published with open access at Springerlink.com

\begin{abstract}
In this study, the immunomodulatory properties of Lawsonia inermis (henna) in common carp, Cyprinus carpio was investigated. Fish were intraperitoneally (i.p.) injected with 6,60 or $600 \mathrm{mg} \mathrm{kg}^{-1}$ body weight (BW), of the methanolic soluble fractions of L. inermis. The extract at 60 and $600 \mathrm{mg} \mathrm{kg}^{-1} \mathrm{BW}$, significantly $(p<0.05)$ enhanced some non-specific immune parameters such as serum lysozyme and bactericidal activity, phagocytic and respiratory burst activity, total leucocyte count (TLC), lymphocyte, monocyte and neutrophil number. Disease resistance against Aeromonas hydrophila has also been improved following herbal treatment. This preliminary study indicates the beneficial effect of $L$. inermis in improving immune status and controlling infectious diseases in aquaculture.
\end{abstract}

Keywords Lawsonia inermis · Common carp · Immune response · Aeromonas hydrophila · Disease resistance

\section{Introduction}

Chemotherapies are widely used by farmers to control and prevent diseases, which have several drawbacks such as environmental risks, development of resistant pathogens and bioaccumulation (Rao et al. 2006). Nowadays, several alternative strategies such as immunostimulants, probiotics, green water technique, vaccination and quorum sensing have been introduced in aquaculture to improve fish resistance to pathogen and improve growth performance (Markestad and Grave 1997; Brekke 1998; Sakai 1999; Rodgers and Furones 2009; Defoirdt et al. 2011; Romero et al. 2012; Sihag and Sharma 2012; Revertera et al. 2014).

Mello et al. (2013) observed an increase in intestinal goblet cell count (GC) in tilapia fed dietary probiotic supplementation. The increase in GC may enable an increase production of mucous, thus increasing intestinal protection against bacterial pathogen.

Immunostimulants mainly facilitate the function of phagocytic and natural killer cells, complement, lysozyme and antibody responses of fish. These effects depends on various factors like timing, dosage and method of administration as well as the physiological condition of the fish (Harikrishnan et al. 2011).

Various kinds of substances have been used and their suitability as immunostimulant has been studied, but only few of them are found suitable for use in aquaculture (Raa et al. 1992; Siwicki et al. 1998). Recently,

\footnotetext{
S. Soltanian $(\bowtie) \cdot$ M. S. Fereidouni

Aquatic Animal Health and Diseases Department, School of Veterinary Medicine, Shiraz University, 71441-69155 Shiraz, Iran

e-mail: siyavashsoltanian@yahoo.com

M. S. Fereidouni

e-mail: saeid.fereidouni@gmail.com
} 
growing interest has been paid to herbal based immunostimulants in aquaculture. Herbal products are cheaper source for therapeutics and biocompatible, biodegradable and safe for the environment (Ortuno et al. 2002; Bricknell and Dalmo 2005).

Lawsonia inermis Linn, popularly known as henna plant, belongs to the family of Lythraceae.

The henna plant is native to North Africa and South-West Asia. It is cultivated in Kerman, Hormozgan, and Baloochestan province of Iran (Rechinger 1968). Henna leaves are very popular natural dye to color hand, finger, nails and hair (Joshi 2000). It contains a pigment called Lawson (2-hydroxy-1, 4-naphthoquinone), mannitol, mucilage, flavonoids such as apigenin, luteolin, quercetin, several phenolic glycosides, coumarin, xanthone, quinoids, glycosides, beta-cytostrol, terpenoids, lipid, resin, tannin, catechin and essence. Other compounds derived from henna leaves are 5-7 glycosides derivatives, gallic acid, acastin glycoside, laxanthon 1 and 2, and small amount of alkaloids (El Babili et al. 2013).

The plant extract or its purified compounds exhibit a variety of biological activities such as antimicrobial activity (Malekzadeh 1968; Abdel-Malek et al. 1973), anti-sickling activity (Chang and Suzuka 1982; Clarke et al. 1986), hepatoprotective activity (Anaad et al. 1992), cytotoxic activity (Ali and Grever 1998), antiinflammatory, antipyretic, and analgesic activities (Ali et al. 1995). Furthermore, anti-diarrheal, antioxidant and regenerative properties as well as neutralizing the free radicals have been reported (Prakash et al. 2007). Moreover, L. inermis has also been used in ethno-medicine to treat various maladies including arthritis, headaches, ulcers, diarrhea, leprosy, intestinal neo-plasticity, jaundice, fever, leucorrhoea, diabetes, and small pox (Elmanama et al. 2011). In addition, in vitro immunomodulatory properties of henna leaves have also been reported (Dikshit et al. 2000; Mikhaeil et al. 2004). More recently, the methanolic extract of L. inermis has been shown to exert an immunomadilatory effect in striped murrels (Channa striatus) (Uthayakumar et al. 2014a). Therefore, the aim of this study was to determine the immunomadilatory activity of L. inermis methanolic extract in common carp.

\section{Materials and methods}

\section{Experimental fish}

Apparently healthy juvenile common carps, with an average initial weight of $46.25 \pm 8 \mathrm{~g}$ were obtained from a fish farm in Shiraz, Fars province, south west of Iran. Fish were acclimated to laboratory conditions in glass tanks for a period of 2 weeks. The health status was examined microbiologically throughout the acclimatization period. During the experimental period, the water was measured at $25 \pm 2{ }^{\circ} \mathrm{C}$, dissolved oxygen 5-5.5 ppm and $\mathrm{pH}$ 7-8. Ammonia, nitrite and nitrate were monitored using a commercial testing kit (Fish Farming Test Kit, Model FF-1A; HACH Co., Loveland, CO, USA) and maintained in standard ranges. During the acclimation and sampling periods, fish were fed twice daily a commercial carp pelleted food (Table 1, Beyza Technology Co., Ltd., Iran) at a feeding rate of $3 \%$ body weight.

Table 1 Composition of commercial diet

\begin{tabular}{lr}
\hline Nutrients & Value \\
\hline Gross energy (Kcal/Kg) & 3500 \\
Crude protein (\%) & $35-37$ \\
Crude lipid (\%) & $9-11$ \\
Crude fiber (\%) & $5 \%$ \\
Moisture (\%) & $<10$ \\
Ash (\%) & $<10$ \\
TVN (mg/100 g) & $<45$ \\
\hline
\end{tabular}

$T V N$ total volatile nitrogen 


\section{Herbal extract}

Lawsonia inermis medicinal plant was collected from herbal medicine shop and its identity was confirmed using monographs by Mozaffarian (1996). About $150 \mathrm{~g}$ of powdered leaves was taken in a clean, flat bottomed glass container and soaked in $1.5 \mathrm{~L}$ of $85 \%$ methanol. The container with its contents was sealed and kept for a period of 7 days accompanying occasional shaking and stirring. The whole mixture then underwent a coarse filtration by a piece of clean, white cotton material. Then, it was filtered through Whatman filter paper (Bibby RE200, Sterilin Ltd., UK). The obtained filtrate (methanol extract) was evaporated using a rotary evaporator. It rendered a gummy concentrate of reddish black color. The gummy concentrate was designated as a crude methanol extract of methanol. The extract was stored in a refrigerator $\left(4^{\circ} \mathrm{C}\right)$ until used.

Experimental design

The experimental fish were divided randomly into four groups (ninety-two fish/group in four replicates) for administration of different doses of methanolic extract of L. inermis injected intraperitoneally $(200 \mu \mathrm{L})$ with

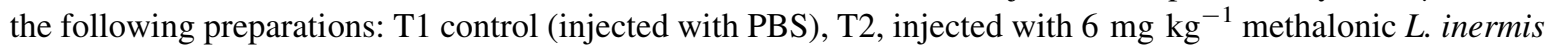
extract, T3, injected with $60 \mathrm{mg} \mathrm{kg}^{-1}$ methalonic L. inermis extract, T4, injected with $600 \mathrm{mg} \mathrm{kg}^{-1}$ methalonic L. inermis extract. Before injection, the extract was filter-sterilized using $0.2 \mu \mathrm{m}$ membrane filters (Whatman, UK).

Blood and serum collection

The fish were bled 2 days prior to and 2, 4, 6, 8 and 10 days after treatment. Six fish from each group were randomly selected and anesthetized using MS $222(0.1 \mathrm{ppm})$. The blood samples were collected from caudal vein using a 2-mL syringe and a 24-gauge needle.

Sampled fish were not returned to the experimental population and were euthanized using an over dose (300 ppm) of MS 222. One part of each blood sample was transferred into preheparinised plastic Eppendorf tubes while the other part was transferred into tubes or Eppendorf tubes without anticoagulant and was allowed to clot for $2 \mathrm{~h}$ at room temperature in a slanting position. Before the serum was collected, the tubes were kept at $4{ }^{\circ} \mathrm{C}$ overnight and were then centrifuged at $2500 \times g$ for $15 \mathrm{~min}$. The serum was stored at $-20{ }^{\circ} \mathrm{C}$ in screwcap glass vials until use.

Determination of serum biochemical and hematological parameters

Blood samples were immediately analyzed for the estimation of numbers of erythrocytes (RBC) and leucocytes (WBC), Hemoglobin (Hb) and Hematocrit levels (\% red blood cells). RBC and WBC counts were performed as described by Schaperclaus et al. (1991). Hemoglobin contents (Hb) were determined using cyanmethemoglobin method with Drabkin's solution (Goldenfarb et al. 1971). Hematocrit was determined by the microhematocrit method (Fox et al. 1997). The leukocyte differential count was done in peripheral blood smears stained with May-Grunwald/Giemsa stains. Leucogram was assessed for each fish under an oil immersion lens. One hundred white blood cells from each smear were assessed and the percentage of different types of leucocytes was calculated (Schaperclaus et al. 1991).

Total serum protein was measured by the Biuret method (Kwapinski 1965). Total serum immunoglobulin (Ig) was measured as previously described by (Siwicki and Anderson 1993). First, Ig was separated from serum by precipitation with polyethylene glycol and remaining protein in the supernatant was assayed. That amount was subtracted from the total protein to give total $\mathrm{Ig}$.

Phagocytic assay

Phagocytic activity was measured following (Siwicki and Anderson 1993) with slight modifications. The heparinized blood was immediately used for the phagocytic assay. Briefly, $1 \times 10^{7}$ cells of Staphylococcus aureus in $0.1 \mathrm{~mL}$ of PBS were added to $0.1 \mathrm{~mL}$ of blood samples in a microplate. This was then incubated for $30 \mathrm{~min}$ at $25^{\circ} \mathrm{C}$ after thorough mixing in the well. 
After incubation, the plate was mixed gently, and $0.05 \mathrm{~mL}$ of this suspension was smeared on the glass slide. After air drying, the smears were fixed in ethanol and stained with Giemsa (7\%). The phagocytic cells were counted. Phagocytic activation (PA) was determined by enumerating 100 phagocytes per slide under a microscope. The mean of the slides was calculated as below; PA: (Number of phagocytic cells with engulfed bacteria/number of phagocytes) $\times 100$.

Lysozyme assay

Serum lysozyme activity was determined using the methods described by (Jian and Wu 2003). Briefly, a suspension of an overnight grown Micrococcus lysodeikticus was prepared by dissolving $20 \mathrm{mg}$ of $M$. lysodeikticus into $100 \mathrm{~mL}$ of $0.067 \mathrm{~mol} / \mathrm{L}$ PBS (pH 6.4) and then, $100 \mu \mathrm{L}$ of fish serum was added to a $3 \mathrm{~mL}$ suspension of M. lysodeikticus. The reaction was carried out at $25 \pm 1{ }^{\circ} \mathrm{C}$, and an absorbance at $540 \mathrm{~nm}$ was measured after 0.5 and $4.5 \mathrm{~min}$. One unit of lysozyme activity was defined as the amount of lysozyme producing a decrease in absorbance of $0.001 / \mathrm{min}$.

Respiratory burst activity

Oxidative radical production by neutrophils during respiratory burst was measured by the NBT assay as described by (Anderson and Siwicki 1995). Briefly, blood and $0.2 \%$ NBT were mixed in equal proportion (1:1), incubated for $30 \mathrm{~min}$ at $25{ }^{\circ} \mathrm{C}$, and then $50 \mu \mathrm{L}$ was taken out and dispensed in glass tubes. For solubilisation of reduced formazen product, $1 \mathrm{~mL}$ of dimethylformamide (Sigma, USA) was added and centrifuged at $2000 \times g$ for 5 min. Finally, the supernatant was taken and the extent of NBT reduced was measured at an optical density of $540 \mathrm{~nm}$. Dimethyl formamide was used as the blank.

Pathogen

A virulent strain of Aeromonas hydrophila (Dehghani et al. 2012), was obtained from Aquatic Animal Health and Diseases Department, Shiraz University, Iran. The virulent strain was isolated from infected fish originating in Iran (Modarres Mousavi Behbahani et al. 2014). Stock cultures were maintained at $-70{ }^{\circ} \mathrm{C}$ in a suspension of tryptic soy broth (TSB) containing $15 \%$ glycerol. For the preparation of bacteria for challenge test, A. hydrophila from stock was cultured for $24 \mathrm{~h}$ at $25{ }^{\circ} \mathrm{C}$ in TSB. The cells were centrifuged $(3000 \times g$ for $15 \mathrm{~min}$ ) and washed three times with sterile (PBS, pH 7.2). The bacterial suspension was adjusted to an optical density of 0.5 at $540 \mathrm{~nm}$, which had been determined to correspond to approximately $10^{8} \mathrm{CFU} \mathrm{ml}{ }^{-1}$. After use, the CFU of the bacterial suspension was counted by the spread plate method on tryptic soy agar (TSA) plates.

Challenge experiment

After the administration of plant extracts, 18 fish from the forth replicate in each group were intraperitoneally injected with $0.1 \mathrm{~mL}$ of a $24 \mathrm{~h}$ growth of virulent $A$. hydrophila $\left(1 \times 10^{8}\right.$ cells/fish $)$ on day 7 . Previously, the challenge dose was adjusted to give $50 \%$ mortality (LD50) in the untreated groups. Mortality was recorded for 15 days. All dead fish and the survivors were examined bacteriologically to determine the presence of the pathogen. The relative percent survival (RPS) was calculated according to Amend (1981):

$$
\text { RPS }=[1-(\text { Mortality }(\%) \text { in treated group }) /(\text { Mortality }(\%) \text { in control group })] \times 100
$$

Serum bactericidal activity

Serum bactericidal activity was determined using the procedure described by Rao et al. (2006). A. hydrophila bacterial culture was centrifuged $(3000 \times g$ for $15 \mathrm{~min})$ and the pellet was washed and suspended in PBS. OD of the suspension was adjusted to 0.5 at $546 \mathrm{~nm}$. This bacterial suspension was serially diluted (1:10) with PBS five times. Serum bactericidal activity was determined by incubating $2 \mathrm{~mL}$ of this diluted A. hydrophila suspension with $20 \mathrm{~mL}$ of serum in a micro-vial for $1 \mathrm{~h}$ at $25^{\circ} \mathrm{C}$. In the bacterial control group, PBS replaced 
the serum. After incubation, the number of viable bacteria was determined by counting the colonies grown on nutrient agar plate for $24 \mathrm{~h}$ at $25^{\circ} \mathrm{C}$.

Statistical analysis

Data are presented as Mean \pm SD of the number of fish per group. Hematological and immune parameters were analyzed by one way analysis of variance (ANOVA) and Tukey's multiple comparison range. All statistical analyses were tested at the 0.05 level of probability, using the software SPSS 16.0 for Windows.

\section{Results}

Phagocytic and NBT activity

Phagocytic activity was significantly enhanced after administration of both medium and high doses of plant extract, peaked on day 8 and 10 (Fig. 1a). NBT activity was significantly higher in groups administered with medium and high doses of plant extract (Fig. 1b). The maximum level was observed in medium dose treatment, recorded on day 10.

Serum lysozyme activity

On most of the days tested, higher serum lysozyme activity was observed in medium and high dose treatment, which was more significant in medium dose treatment (Fig. 1c).

Serum biochemical and hematological parameters

The effects of different levels of henna extract on hematological and biochemical parameters of common carp are shown in Fig. 1a-j; Table 2. The Hb, Hct and RBC values were not affected by all three dosages of plant extract $(p>0.05)$ (Table 2).

Total serum protein content in the fish injected with either medium dose $\left(60 \mathrm{mg} \mathrm{kg}^{-1} \mathrm{BW}\right)$ or high dose $\left(600 \mathrm{mg} \mathrm{kg}^{-1} \mathrm{BW}\right)$ of plant extract was significantly $(p<0.05)$ higher than control fish on day 6,8 and 10 post- treatment (Fig. 1d), peaked on day 10 , in the fish received the medium dose $\left(60 \mathrm{mg} \mathrm{kg}^{-1} \mathrm{BW}\right)$.

Serum globulin content was significantly higher than control on day 8 only in the fish injected with high dose $\left(600 \mathrm{mg} \mathrm{kg}^{-1} \mathrm{BW}\right)$ of plant extract and on day 10 in the fish treated with both medium and high doses of plant extract (Fig. 1e). However, no significant $(p>0.05)$ impact on serum globulin level was observed in other groups on different days tested.

After the treatment, an increasing trend was observed in WBC number on all the assay days (Fig. 1f). Both medium and high doses of plant extract could significantly increase the number of WBC on the 6th and 8th day in comparison with control fish.

Fish leucogram was significantly affected by plant extract administration. On all days tested, significantly, lower percentage (proportion) of lymphocytes was observed in fish administrated with both medium and high doses of plant extract compared with the control group (Fig. 1g), although the total number of lymphocyte remained unchanged.

Despite to lymphocytes, the number of monocytes and granulocytes was always significantly enhanced in both medium and high dose treatments in comparison to control group (Fig. 1h, i), yet, a decreasing trend in the number of these cells was observed from day 6 and 8 onwards, respectively.

Serum bactericidal activity

During the assay period, the number of viable bacterial colonies showed a time course dependent decreasing trend in the fish treated with plant extract. Serum bactericidal activity was lowest in the control group and highest in T4 and T5 group recorded on day $10(p<0.05)$ (Fig. 1j). The viable bacterial counts were 

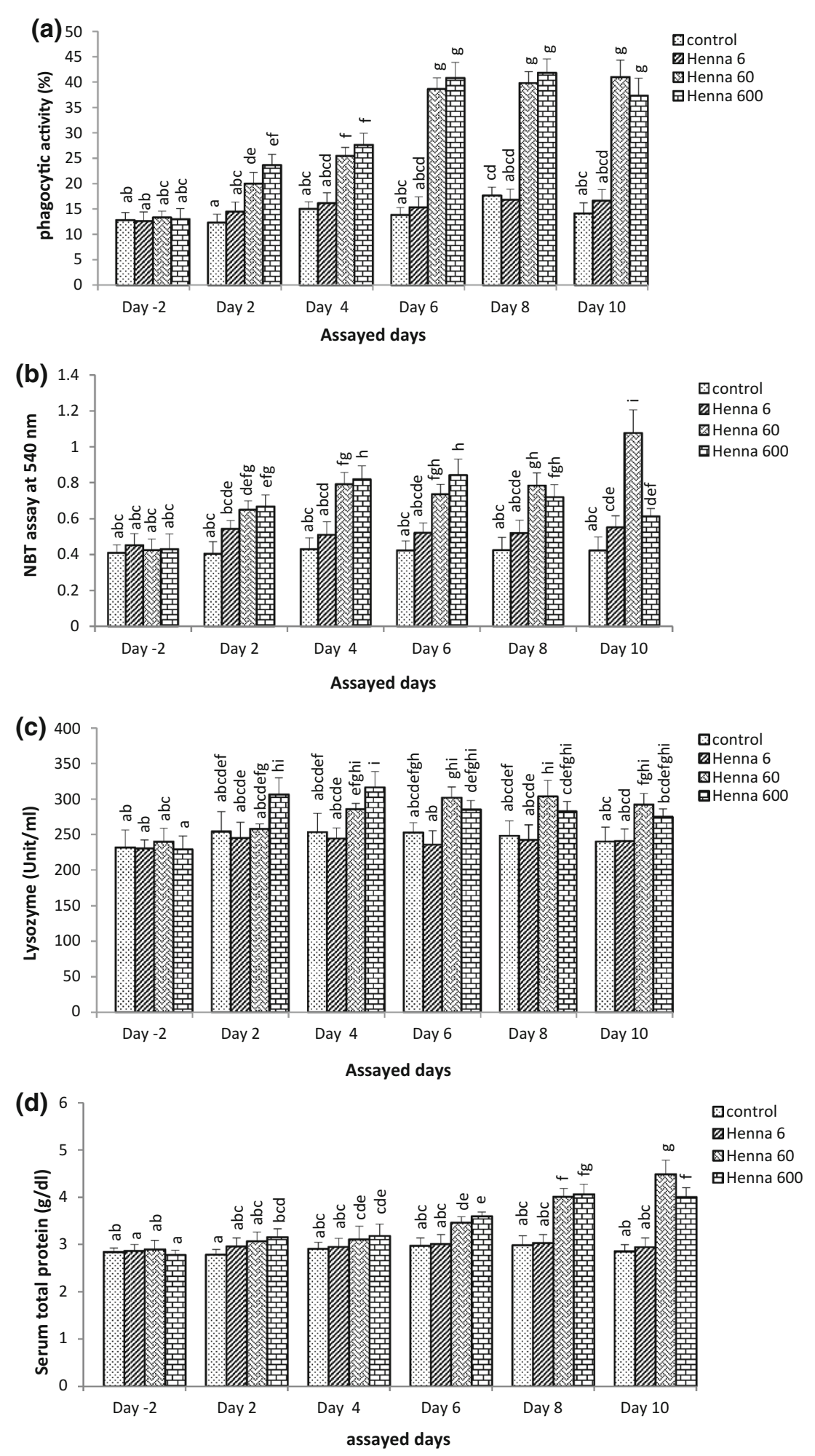

Fig. 1 Hemato-immunological parameters in common carp intraperitoneally injected with single doses of 6,60 and $600 \mathrm{mg} \mathrm{kg}{ }^{-1} \mathrm{BW}$ fish of a methanolic extract of Henna (L. inermis) on days 2, 4, 6,8 and 10 post-injection. a Phagocytic activity; b NBT activity; c lysozyme activity; d serum total protein level; e serum immunoglobulin level; f WBC number; g lymphocyte (\%); $\mathbf{h}$ monocyte (\%); $\mathbf{i}$ granulocyte (\%); $\mathbf{j}$ serum bactericidal activity. Bars represent mean \pm SD from six fish sampled at each time point $(n=6)$. Different letters over bars represent significant difference $(p$ Tukey $<0.05)$ 

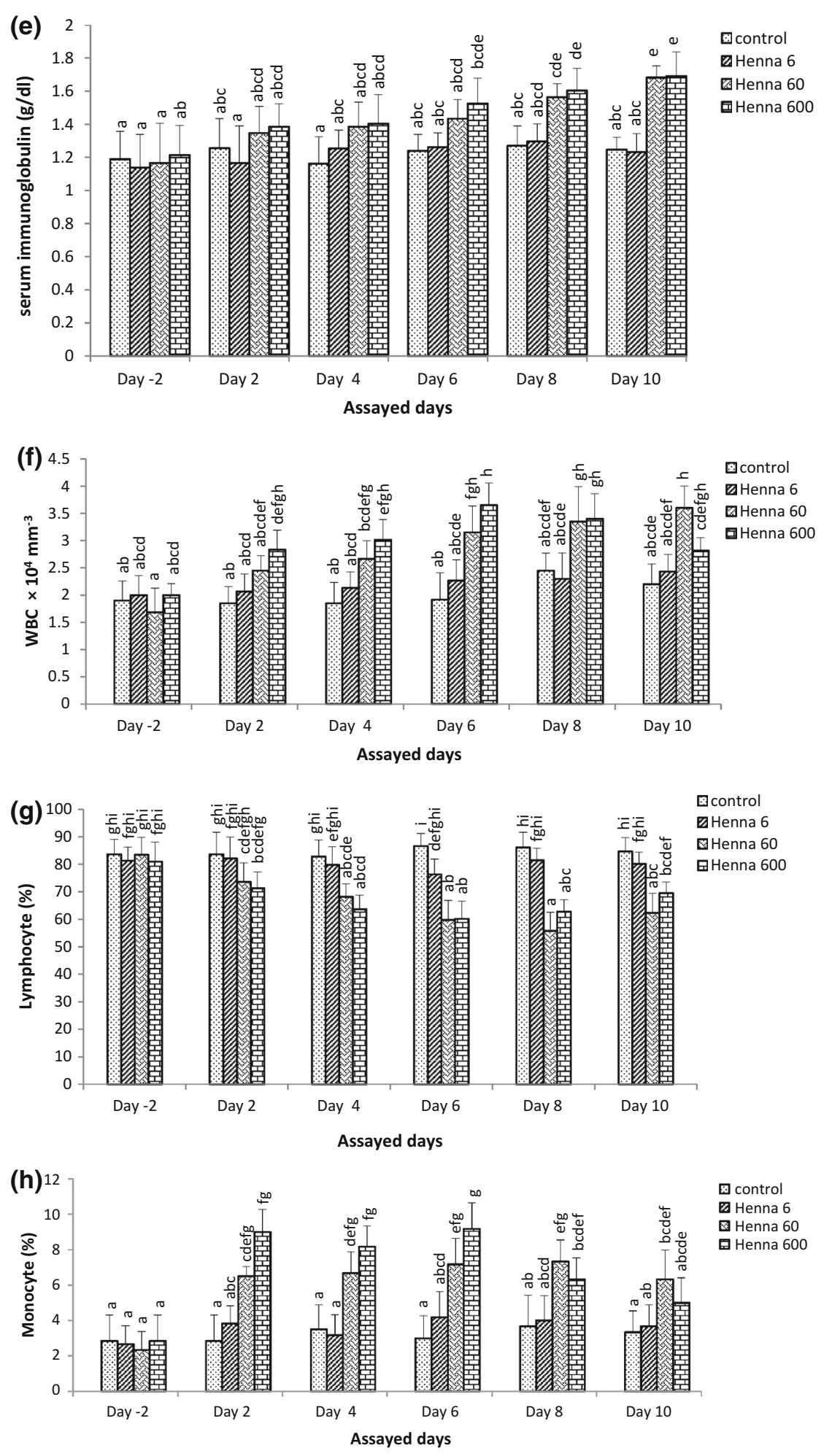

Fig. 1 continued 

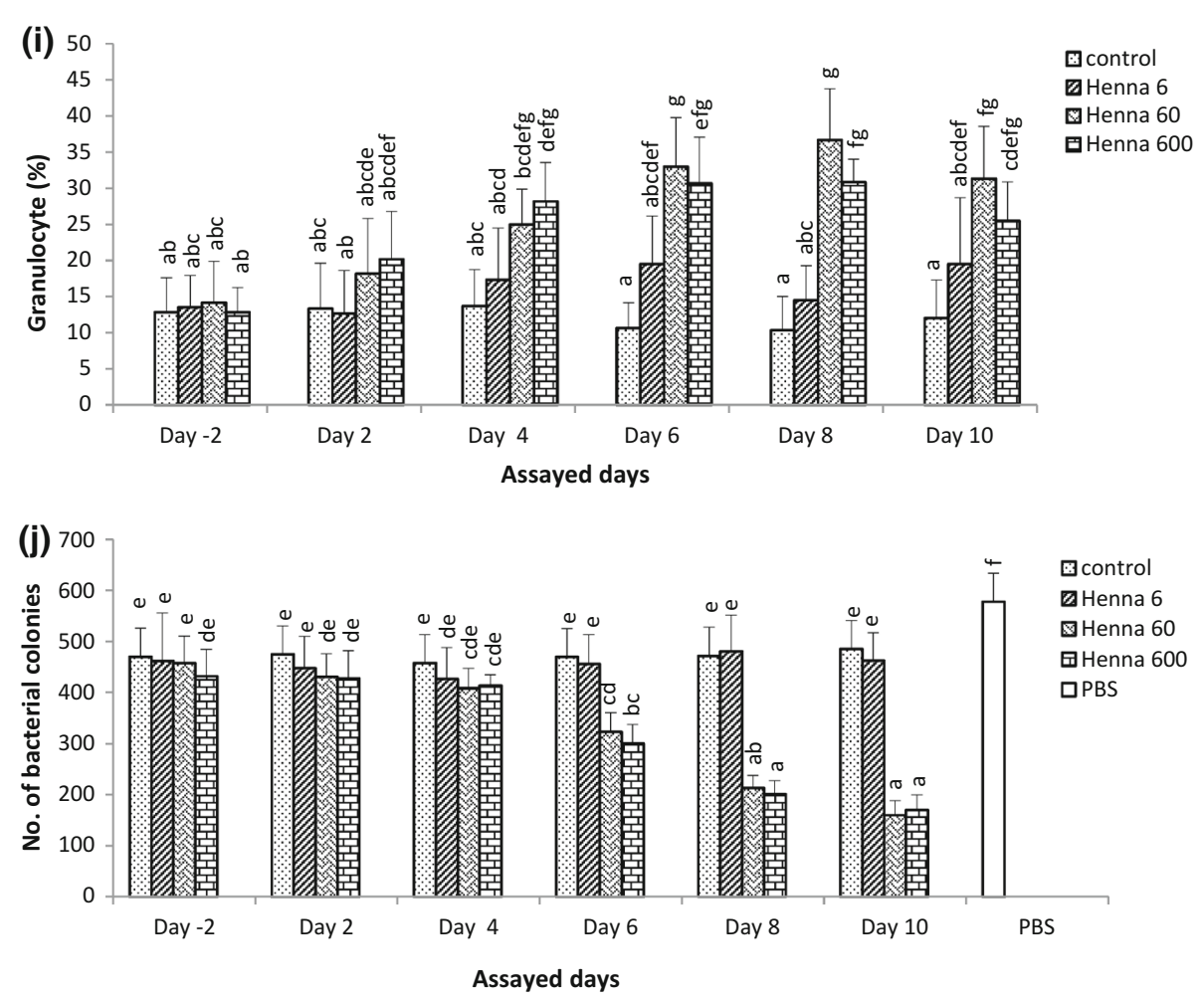

Fig. 1 continued

significantly $(p<0.05)$ lower in T4 and T5 group compared with either untreated control group or bacterial control (without serum treatment).

Disease resistance

The mortality rate was decreased (Table 3 ) in fish challenged with virulent A. hydrophila by extract administration. The mortality percentage was found highest $(55.5 \%)$ in the control group (infected fish) and lowest $(27.7 \%)$ in T5 group. The RPS value was significantly highest $(50.0 \%)$ in T5 group followed by T4 and T3 group, respectively $(p<0.05)$ (Table 3$)$.

\section{Discussion}

In the recent years, there is an increasing interest in the use of herbal extracts for disease control and prevention in aquaculture, indicating that they can modulate immune function in farmed species.

The major components of fish immune system are macrophages, monocytes, granulocytes, and humoral elements, such as lysozymes, immunoglobulins and the complement system (Secombes and Fletcher 1992; Magnadóttir 2006). In this study, following i.p. administration of methanolic soluble fractions of $L$. inermis leaves at different doses $\left(6,60\right.$ and $\left.600 \mathrm{mg} \mathrm{kg}^{-1} \mathrm{BW}\right)$, Several immune parameters such as phagocytic and NBT activities, serum immunoglobulin, lysozyme and total protein level, RBC and WBC number, hematocrit and $\mathrm{Hb}$ value, the percentage of lymphocyte (\%), monocyte (\%), neutrophil (\%) and serum bactericidal activity were evaluated in 2 days intervals (Table 2; Fig. 1a-j).

Data showed that methanolic extract of $L$. inermis significantly enhanced the non-specific humoral and cellular responses and disease resistance against $A$. hydrophila. All the above immune indices, however, were found to be affected in a time and dose-dependent manner. 
Previously, in vitro studies revealed that the methanolic extract of $L$. inermis displayed immunostimulatory effect as indicated by an enhanced macrophage-stimulating activity and promotion of T-lymphocyte proliferative responses in human (Wagner et al. 1988; Mikhaeil et al. 2004).

Phagocytosis and killing activity by neutrophils and macrophages is an important defense mechanism against pathogenic bacteria (Rao et al. 2006). Previously, enhancement of phagocytic and NBT activities following administration of herbal products in fish species have been reported in a number of studies (Rao et al. 2006; Sahu et al. 2007; Punitha et al. 2008; Pratheepa et al. 2010; Sharma et al. 2010; Behera et al. 2011; Uthayakumar et al. 2014b; Anusha et al. 2014).

In this study, phagocytic activity was significantly enhanced in the common carp after administration of both medium and high doses of plant extract, peaked on day 8 and 10 post- treatment. Similar results were found in Carassius auratus fed crude extracts and purified fractions of Ixora coccinea incorporated in diet (Anusha et al. 2014).

Likewise, NBT activity was significantly higher in groups treated with medium and high doses of plant extract. However, for both phagocytic and NBT activities, maximum values were observed in medium dose treatment recorded on day 10.

Lysozyme plays an important role in innate immunity by lysis of bacterial cell wall and thus stimulates the phagocytosis of bacteria. In this work, the most significant highest lysozyme activity was observed in medium dose treatment. In a similar study, following intraperitoneal administration of different doses (4, 40 or $400 \mathrm{mg} \mathrm{kg}^{-1} \mathrm{BW}$ ) of water extract of Solanum trilobatum leaves in Oreochromis mossambicus, only the medium dose (40 $\mathrm{mg} \mathrm{kg}^{-1} \mathrm{BW}$ ) could significantly enhance lysozyme activity on day 4, 6 and 8 posttreatment (Divyagnaneswari et al. 2008). In another study, among various doses of an aqueous extract of Polygonum minus leaf, intraperitoneally injected to African catfish, Clarias gariepinus, only the dose of $15 \mathrm{mg} \mathrm{kg}{ }^{-1} \mathrm{BW}$ of plant extract could significantly improve lysozyme activity 2 days post-treatment (Veerasamy et al. 2014). Similar results of elevated lysozyme activity following herbal treatments have been reported (Jian and Wu 2003, 2004; Rao et al. 2006; Yin et al. 2006; Anusha et al. 2014).

Serum protein level is an important indicator of humoral defense system and health status of fish species. In fact, immunostimulants can stimulate protein synthesis to produce more of the molecules involved in immunity such as immunoglobulins, complement, lysozyme, and anti-proteases (Rao et al. 2006). This study revealed that administration of both medium and high dose of henna extract could significantly increase both serum protein and immunoglobulin level in common carp. The increase in serum protein content might be in part due to an increase in the WBC number, which is a major source of serum protein production such as immunoglobulin, lysozyme, complement factors and bactericidal peptides (Misra et al. 2006a, b). This is supported by an enhancement in WBC number in the group that administrated with medium or high dose of henna extract.

A significant increase was reported in serum protein and total immunoglobulin level of rainbow trout fed basal diet incorporated with 1, 2.5 and $5 \%$ black Cumin Seeds, Nigella sativa for 21 days (Dorucu et al. 2009). Furthermore, dietary garlic, onion and ginger could significantly increase total immunoglobulin level in rainbow trout (Nya and Austin 2009) and in the brown marbled grouper, Epinephelus fuscoguttatus (ApinesAmar et al. 2012). In addition, elevated total protein and globulin was reported following administration of medicinal plants in fish species (Dugenci et al. 2003; Misra et al. 2006a; Rao et al. 2006; Yins et al. 2008; Alishahi et al. 2010, 2012; Alishahi and Abdy 2013).

Hematological parameters are used as an index of fish health status to detect physiological changes following different stress conditions such as abnormalities caused by immunostimulants (Agrawal and Mahajan 1980). In this study, no significant difference in the haemoglobin, hematocrit and total erythrocyte count was observed following herbal administration indicating that at such treatment condition no toxic reactions detrimental to the fish were elicited.

Total and differential leucocyte counts are important indices of non-specific defense activities in fish (De Pedro et al. 2005).

Treatment with either medium or high dose of L. inermis extract significantly increased total leukocyte count (TLC) as well as lymphocytes, monocytes and neutrophils number compared with control group. However, maximum effect was observed on day 8 in medium dose treatment. This increment might be in part due to the activation of the haemopoietic tissues by L. inermis as previously reported in rainbow trout following in vitro treatment of macrophages with Glycyrrhiza glabra extract (Jang et al. 1995). Similar 
Table $2 \mathrm{RBC}$, Hct and $\mathrm{Hb}$ valuesin common carpintraperitoneally injected with single doses of 6, 60 and $600 \mathrm{mg} \mathrm{kg}^{-1} \mathrm{BW}$ fish of a methanolic extract of Henna ( $L$. inermis) on days 2, 4, 6, 8 and 10 post-injection

\begin{tabular}{|c|c|c|c|c|}
\hline Injection days & Fish group & $\mathrm{RBC} \times 10^{6} / \mathrm{mm}^{3}$ & Hematocrit $(\%)$ & $\mathrm{Hb}(\mathrm{g} / \mathrm{dl})$ \\
\hline \multirow[t]{4}{*}{-2} & Control (saline injected) & $1.46 \pm 0.22$ & $39.2 \pm 3.64$ & $8.48 \pm 1.3$ \\
\hline & Henna extract $\left(6 \mathrm{mg} \mathrm{kg}^{-1} \mathrm{BW}\right)$ & $1.53 \pm 0.18$ & $38.4 \pm 4.22$ & $7.85 \pm 0.88$ \\
\hline & Henna extract $\left(60 \mathrm{mg} \mathrm{kg}^{-1} \mathrm{BW}\right)$ & $1.40 \pm 0.23$ & $38.6 \pm 3.18$ & $7.68 \pm 0.77$ \\
\hline & Henna extract $\left(600 \mathrm{mg} \mathrm{kg}^{-1} \mathrm{BW}\right)$ & $1.38 \pm 0.33$ & $38.2 \pm 4.62$ & $7.35 \pm 1.2$ \\
\hline \multirow[t]{4}{*}{2} & Control (saline injected) & $1.52 \pm 0.26$ & $39.8 \pm 2.2$ & $8.66 \pm 0.56$ \\
\hline & Henna extract $\left(6 \mathrm{mg} \mathrm{kg}^{-1} \mathrm{BW}\right)$ & $1.44 \pm 0.20$ & $38.3 \pm 4.7$ & $7.82 \pm 1.3$ \\
\hline & Henna extract $\left(60 \mathrm{mg} \mathrm{kg}^{-1} \mathrm{BW}\right)$ & $1.42 \pm 0.28$ & $40 \pm 3.3$ & $7.78 \pm 0.61$ \\
\hline & Henna extract $\left(600 \mathrm{mg} \mathrm{kg}^{-1} \mathrm{BW}\right)$ & $1.35 \pm 0.36$ & $38.2 \pm 3.6$ & $7.52 \pm 1.14$ \\
\hline \multirow[t]{4}{*}{4} & Control (saline injected) & $1.54 \pm 0.28$ & $42.6 \pm 3.3$ & $8.32 \pm 0.56$ \\
\hline & Henna extract $\left(6 \mathrm{mgkg}^{-1} \mathrm{BW}\right)$ & $1.44 \pm 0.16$ & $40.2 \pm 3.1$ & $7.20 \pm 0.72$ \\
\hline & Henna extract $\left(60 \mathrm{mgkg}^{-1} \mathrm{BW}\right)$ & $1.42 \pm 0.18$ & $39.3 \pm 3.6$ & $7.22 \pm 0.83$ \\
\hline & Henna extract $\left(600 \mathrm{mgkg}^{-1} \mathrm{BW}\right)$ & $1.36 \pm 0.26$ & $38.5 \pm 4.4$ & $7.55 \pm 0.73$ \\
\hline \multirow[t]{4}{*}{6} & Control (saline injected) & $1.56 \pm 0.24$ & $39.3 \pm 3.3$ & $8.28 \pm 1.18$ \\
\hline & Henna extract $\left(6 \mathrm{mgkg}^{-1} \mathrm{BW}\right)$ & $1.52 \pm 0.19$ & $39.6 \pm 5.2$ & $7.62 \pm 1.12$ \\
\hline & Henna extract $\left(60 \mathrm{mgkg}^{-1} \mathrm{BW}\right)$ & $1.42 \pm 0.23$ & $39.2 \pm 3.4$ & $7.53 \pm 0.7$ \\
\hline & Henna extract $\left(600 \mathrm{mgkg}^{-1} \mathrm{BW}\right)$ & $1.37 \pm 0.27$ & $38.6 \pm 3.2$ & $7.48 \pm 1.14$ \\
\hline \multirow[t]{4}{*}{8} & Control (saline injected) & $1.62 \pm 0.24$ & $42.3 \pm 2.7$ & $8.56 \pm 0.68$ \\
\hline & Henna extract $\left(6 \mathrm{mg} \mathrm{kg}^{-1} \mathrm{BW}\right)$ & $1.44 \pm 0.18$ & $39.3 \pm 4.7$ & $7.32 \pm 1.24$ \\
\hline & Hennar extract $\left(60 \mathrm{mg} \mathrm{kg}^{-1} \mathrm{BW}\right)$ & $1.39 \pm 0.26$ & $38.4 \pm 2.6$ & $7.85 \pm 0.58$ \\
\hline & Henna extract $\left(600 \mathrm{mgkg}^{-1} \mathrm{BW}\right)$ & $1.37 \pm 0.33$ & $38.8 \pm 2.4$ & $7.62 \pm 0.64$ \\
\hline \multirow[t]{4}{*}{10} & Control (saline injected) & $1.58 \pm 0.21$ & $39.5 \pm 2.3$ & $8.73 \pm 0.58$ \\
\hline & Henna extract $\left(6 \mathrm{mg} \mathrm{kg}^{-1} \mathrm{BW}\right)$ & $1.45 \pm 0.34$ & $38.3 \pm 4.6$ & $7.48 \pm 1.12$ \\
\hline & Henna extract $\left(60 \mathrm{mg} \mathrm{kg}^{-1} \mathrm{BW}\right)$ & $1.38 \pm 0.26$ & $39.4 \pm 3.8$ & $7.46 \pm 0.79$ \\
\hline & Henna extract $\left(600 \mathrm{mg} \mathrm{kg}^{-1} \mathrm{BW}\right)$ & $1.37 \pm 0.28$ & $38.2 \pm 2.2$ & $7.28 \pm 0.64$ \\
\hline
\end{tabular}

Values are presented with the respective standard deviation (mean $\pm \mathrm{SD})(n=6)$. Values in the same column showing the same superscript letter are not significantly different $(p$ Tukey $>0.05)$

Table 3 Effect of L. inermis (Henna) administration by intraperitoneal injection on relative percent survival (RPS) against LD50 concentration of $A$. hydrophila in common carp

\begin{tabular}{lll}
\hline Treatment & Mortality (\%) & RPS (\%) \\
\hline Control (saline injected) & 55.5 & - \\
Henna extract $\left(6 \mathrm{mg} \mathrm{kg}^{-1} \mathrm{BW}\right)$ & 44.4 & 20.0 \\
Henna extract $\left(60 \mathrm{mg} \mathrm{kg}^{-1} \mathrm{BW}\right)$ & 27.7 & $50.0^{*}$ \\
Henna extract $\left(600 \mathrm{mg} \mathrm{kg}^{-1} \mathrm{BW}\right)$ & 33.3 & $40.0^{*}$ \\
\hline
\end{tabular}

RPS values with asterisk $(*)$ differ significantly $(p<0.05)$ with control. Data expressed as mean \pm SD $(n=18)$

findings were obtained by Barrett (2003) and Widel et al. (2003), who reported that Echinacea preparations influenced the leukocyte count. Likewise, dietary garlic exhibited an increased level of WBC, lymphocytes, monocytes and neutrophils in C. carpio (Iranloye 2002). Furthermore, similar findings were observed in Cirrhinus mrigala fed with ginger and turmeric supplementations (Sivagurunathan et al. 2011) and in beluga (Huso huso) fed with garlic (Allium sativum) and nettle (Urtica dioica) supplemented diet (Nobahar et al. 2014). It is supposed that, increase in TLC especially in lymphocyte number may be in part due to the presence of flavonoids and terpenoids (Grayer et al. 1996; Lembberkovics et al. 1998; Sayyah et al. 2005) found in L. inermis. 
Lymphocytes were functioned to produce antibody, to acknowledge and respond the antigen, and to be a mediator of cellular and humoral immune responses (Abbas et al. 2010). The significant increase in lymphocytes number in this study might also indicate the specific immunostimulatory role of $L$. inermis as previously reported for Echinacea purpurea (Aly et al. 2008).

Monocytes play important role in the defense system of fish body. They undergo transformation into macrophages and may be involved in phagocytosis and killing of pathogens upon first recognition and subsequent infections (Sivagurunathan et al. 2011). Monocytes have been reported to be sporadic in carp, tench, European catfish, rainbow trout, bream and perch (Mastoi et al. 2012). Nonetheless, in this study, a significant increased number of monocytes were recorded in the fish treated with medium or high dose of plant extract. In addition, the number of neutrophils was also increased. Neutrophils are the first cells to respond to infection within $24 \mathrm{~h}$, increases during bacterial infections to phagocytose them (Sivagurunathan et al. 2011). Thus, increase in the TLC, neutrophils and monocytes in L. inermis extract treated fish can be attributed to the enhancement of non-specific immune responses, whereas increase in lymphocytes number may indicate a specific immune induction. These findings are supported with the results of previous investigations (Aly et al. 2008; Abdel-Tawwab et al. 2010; Sivagurunathan et al. 2012; Antache et al. 2014; Nobahar et al. 2014).

The presence of antimicrobial agents in fish blood can be evaluated by serum bactericidal activity and this is an important tool to analyze the innate immune system (Biller-Takahashi et al. 2013). In fact, independently of the effect of molecules and the mechanisms involved in the microbial killing, the measurement of the microbicidal activity is a very realistic approximation (Guardiola Abellán 2014). In this study, the increase in total serum protein and globulin level following herbal treatment, indicate the raise in protective proteins which can be correlated to the enhanced serum bactericidal activity (Ellis 1999; 2001; Magnadottir 2006; Maqsood et al. 2009). In this regard, a time course decreasing trend was observed in the number of bacterial colonies in the groups treated with either the medium or high dose of plant extract (Fig. $1 \mathrm{j}$ ). The minimum number of bacterial colonies was recorded on day 10 post-treatment. Similarly, Quil-A, a fraction from Quillaja saponaria Molina, has enhanced serum bactericidal activity in Salmo gairdneri Richardson (Grayson et al. 1987). In addition, an increase in serum bactericidal activity in tilapia (Divyagnaneswari et al. 2008) in Indian major carp (Rao et al. 2006), in common carp (Alishahi and Abdy 2013) and in ornamental gold fish (Anusha et al. 2014) has reported after the administration of various herbal extracts.

For testing efficacy of an immunostimulant, it is very essential to estimate the increased protection in treated fish (Sakai et al. 2001). Current data revealed that mortality following challenge with A. hydrophila was decreased in the group of fish treated with either medium or high dose of herbal extract. There was an inverse relationship between the mortality rate and the level of extract administration. The enhancement of nonspecific immune parameters by $L$. inermis seed preparation is possibly an important factor in reducing the percentage mortality and thereby protecting the fish against live A. hydrophila challenge.

Earlier studies also revealed that dietary supplementation of Ocimum sanctum and Nyctanthes arbortristis leaves and intraperitoneal injection of water and hexane soluble fraction of Solanum trilobatum and Eclipta alba leaves enhanced the disease resistance against A. hydrophila in O. mossambicus (Logambal et al. 2000; Divyagnaneswari et al. 2008). This finding is in agreement with the results of Abutbul et al. (2004) in tilapia fed with a diet containing ethyl acetate extract of Rosmarinus officinalis leaf powder and where the disease resistance against $A$. hydrophila was enhanced in L. rohita fed with $0.5 \%$ of Achyranthes aspera (Rao et al. 2006). Similar results were found in Carassius auratus fed crude extracts and purified fractions of Ixora coccinea incorporated in diet. Following challenge with highly virulent A. hydrophila AHV-1 the control diet fed fishes succumbed to death within 5 days at $100 \%$ mortality whereas crude extracts and purified fractions fed groups survived 60 and $80 \%$, respectively, after 10 days (Anusha et al. 2014).

Mortality and relative percentage of survival (RPS) of common carp treated with henna extract and the control group after challenging with A. hydrophila is presented in Table 3. The RPS was highest (50.0 \%) in medium dose treatment followed by high dose treatment $(40.0 \%)$ and was lowest $(20.0 \%)$ in low dose treatment. This might be due to the enhancement of the non-specific immune system of the fish by L. inermis. The RPS was strongly correlated with hematological studies and functional assays performed under the conditions of this study. These data are in agreement with the finding of Logambal et al. (2000) and Christybapita et al. (2007) in O. mossambicus, treated with O. sanctum and Eclipta alba leaf extract, respectively. Moreover, similar findings were obtained by an intraperitoneal administration of Solanum trilobatum Leaf extracts in O. mossambicus (Divyagnaneswari et al. 2008). 
Collectively, it can be concluded that the protective ability of $L$. inermisis mediated through specific and non-specific immune mechanisms, as evident from the enhanced lymphocyte number and total immunoglobulin level as well as elevated phagocytic, NBT and lysozyme activities besides positive influence on haematological and biochemical parameters.

The results of the present investigation show that L. inermis methanolic extract can act as an immunostimulant based on a time- and dose-dependent manner. Due to its effectiveness at low concentration, its use could be very cost effective. It is biodegradable and hence environment-friendly. Besides, L. inermis might have potential as an additive to fish feed. However, appropriate field trials remain necessary before using $L$. inermis extract as an immunostimulant in aquaculture.

Acknowledgments This study was supported by the Aquatic Animal Health and Diseases Department, School of Veterinary Medicine, Shiraz University through a research grant to S. Soltanian.

Open Access This article is distributed under the terms of the Creative Commons Attribution 4.0 International License (http:// creativecommons.org/licenses/by/4.0/), which permits unrestricted use, distribution, and reproduction in any medium, provided you give appropriate credit to the original author(s) and the source, provide a link to the Creative Commons license, and indicate if changes were made.

\section{References}

Abbas AK, Licthman AH, Pillai S (2010) Cellular and molecular immunology, 6th edn. W. B. Saunders Company, Philadelphia, pp 6-38

Abdel-Malek YA, El-Leithy MA, Reda FA, Khalil M (1973) Antimicrobial principles in leaves of Lawsonia inermis L. Zentralbl Bakteriol Parasitenkd Infektionskr Hyg 128:61-67

Abdel-Tawwab M, Ahmad MH, Seden MEA, Sakr SFM (2010) Use of green tea, Camellia sinensis L, in practical diet for growth and production of Nile Tilapia, Oreochromis niloticus (L) against Aeromonas hydrophila infection. J World Aquac Soc 41:203-213

Abutbul S, Golan-Goldhirsh A, Barazani O, Zilberg D (2004) Use of Rosmarinus officinalis as a treatment against Streptococcus iniae in tilapia (Oreochromis sp.). Aquaculture 238:97-105

Agrawal NK, Mahajan CL (1980) Haematological changes due to vitamin C deficiency in Channab punctatus Bloch. J Nutr 110:2172-2181

Ali M, Grever MR (1998) A cytotoxic naphthoquinone from Lawsonia inermis. Fitoterapia LXIX(2):1810-1813

Ali BH, Bashir AK, Tanira MO (1995) Anti- inflammatory, antipyretic, and analgesic effects of Lawsonia inermis L. (henna) in rats. Pharmacology 51:356-363

Alishahi M, Abdy E (2013) Effects of different levels of Aloe vera L. extract on growth performance, hemato-immunological indices of Cyprinus carpio L. Iran J Vet Sci Technol 5(2):33-44

Alishahi M, Ranjbar MM, Ghorbanpour M, Peyghan R, Mesbah M, Razijalali M (2010) Effects of dietary Aloe vera on specific and nonspecific immunity of Common carp (Cyprinus carpio). J Vet Res 4(3):85-91

Alishahi M, Ghorbanpour M, Peyghan R (2012) Effects of Viscum album Linnaeus and Nigella sativa Linnaeus extracts on some immune responses of common carp Cyprinus carpio Linnaeus. Asian Fish Sci 25:15-28

Aly SM, Mohammed MF, John G (2008) Echinacea as immunostimulatory agent in Nile tilapia (Oreochromis niloticus) via earthen pond experiment. In: 8th international symposium on Tilapia in aquaculture, pp 1033-1041

Amend DF (1981) Fish biologies: serodiagnostics and vaccines. development in biological standardization 49. In: Anderson DP, Hennessen H (eds) Potency testing of fish vaccines. Karger, Basel, pp 447-454

Anaad KK, Singh B, Chand D, Chandon BK (1992) An evaluation of Lawsonia alba extract as hepatoprotective agent. Planta Med $58: 22-25$

Anderson DP, Siwicki AK (1995) Basic hematology and serology for fish health programs. In: Shariff M, Auther JR, Subasinghe RP (eds) Diseases in asian aquaculture II. Fish Health Section, Asian Fisheries Society, Manila, pp 185-202

Antache A, Cristea V, Grecu I, Dediu L, Creţu M, Petrea M (2014) The influence of some phytobiotics on haematological and some biochemical indices at Oreochromis niloticus-Linnaeus, 1758. Anim Sci Biotechnol 47(1):192-199

Anusha P, Thangaviji V, Velmurugan S, Michaelbabu M, Citarasu T (2014) Protection of Ornamentel Gold fish Carrasius auratus against Aeromonas hydrophila by treating Ixora coccinea active principles. Fish Shellfish Immunol 36:485-493

Apines-Amar MJS, Amar EC, Faisan JP Jr, Pakingking RV Jr, Satoh S (2012) Dietary onion and ginger enhance growth, hematoimmunological responses, and disease resistance in brown-marbled grouper, Epinephelus fuscoguttatus. AACL Bioflux 5(4):231-239

Barrett B (2003) Medicinal properties of Echinacea: a critical review. Phytomedicine 10:66-86

Behera T, Swain P, Sahoo SK, Mohapatra D, Das BK (2011) Immunomodulatory effects of curcumin in fish, Labeo rohita (H.). Indian J Nat Prod Resour 2(2):184-188

Biller-Takahashi JD, Takahashi LS, Pilarski F, Sebastião FA, Urbinati EC (2013) Serum bactericidal activity as indicator of innate immunity in pacu Piaractus mesopotamicus (Holmberg, 1887). Arquivo Brasileiro de Medicina Veterinária e Zootecnia 65(6):1745-1751 
Brekke KA (1998) Fisheries, sealing, whaling and fish farming. In: Natural resources and the environment, Chapter 9, Research Council of Norway, Statistics Norway, ISBN 82-537-4544-3, pp 159-168

Bricknell I, Dalmo RA (2005) The use of immunostimulants in fish larval aquaculture. Fish Shellfish Immunol 19:457-472

Chang H, Suzuka SE (1982) Lawsone (2-OH-1, 4- naphthoquinone) derived from the henna plant increases the oxygen affinity of sickle cell blood. Biochem Biophys Res Commun 107:602-608

Christybapita D, Divyagnaneswari M, Michael RD (2007) Oral administration of Eclipta alba leaf aqueous extract enhances the non-specific immune responses and disease resistance of Oreochromis mossambicus. Fish Shellfish Immunol 23:840-852

Clarke DT, Jones GR, Martin MM (1986) The anti-sickling drug lawsone (2-OH-1, 4-naphthoquinone) protects sickled cells against membrane damage. Biochem Biophys Res Commun 139:780-786

de Pedro N, Guijarro AI, Lopez-Patino MA, Martinez-Alvarez MJ, Delgado R (2005) Daily and seasonal variations in hematological and blood biochemical parameters in the tench, Tinca tinca Linnaeus, 1758. Aquac Res 36:1185-1196

Defoirdt T, Sorgeloos P, Bossier P (2011) Alternatives to antibiotics for the control of bacterial disease in aquaculture. Curr Opin Microbiol 14(3):251-258

Dehghani S, Akhlaghi M, Dehghani M (2012) Efficacy of formalin-killed, heat-killed and lipopolysaccharide vaccines against motile aeromonads infection in rainbow trout (Oncorhynchus mykiss). Glob Vet 9:409-415

Dikshit V, Dikshit J, Saraf M, Thakur V, Sainis K (2000) Immunomodulatory activity ofnaphthoquinone fraction of Lawsonia inermis Linn. Phytomedicine (Jena) 7:102-103

Divyagnaneswari M, Christybapita D, Dinakaran RM (2008) Immunomodulatory activity of Solanum trilobatum leaf extracts in Oreochromis niloticus, pp. 221-234. In: Bondad-Reantaso MG, Mohan CV, Crumlish M, Subasinghe RP (eds) Diseases in asian aquaculture VI. Fish Health Section, Asian Fisheries Society, Manila, p 505

Dorucu M, Colak SO, Ispir U, Altinterim B, Celayir Y (2009) The effect of black cumin seeds, Nigella sativa, on the immune response of rainbow trout,Oncorhynchus mykiss. Mediterr Aquac J 2(1):27-33

Dugenci SK, Arda N, Candan A (2003) Some medicinal plants as immunostimulant for fish. J Ethnopharmacol 88(1):99-106

El Babili F, Valentin A, Chatelain C (2013) Lawsonia inermis: its anatomy and its antimalarial, antioxidant and human breast cancer cells MCF7 activities. Pharm Analytica Acta 4:1

Ellis AE (1988) Fish Vaccination. Academic Press, London

Ellis AE (1999) Immunity to bacteria in fish. Fish Shellfish Immunol 9:291-308

Ellis AE (2001) Innate host defense mechanism of fish against virus and bacteria. Dev Comp Immunol 25:827-839

Elmanama AA, Alyazji AA, Gheneima NAA (2011) Antibacterial, antifungal and synergistic effect of Lawsonia inermis, Punica granatum and Hibiscus sabdariffa. Ann Alquds Med 7:33-41

Fox HE, White SA, Koa MF, Fernald RD (1997) Stress and dominance in a social fish. J Neurosci 16:6463-6469

Goldenfarb PB, Bowyer FP, Hall T, Brosious E (1971) Reproducibility in the hematology laboratory: the microhematocrit determination. Am J Clin Pathol 56:35-39

Grayer RJ, Kite GC, Goldstone FJ, Bryan SE, Paton A, Putievsky E (1996) Intraspecific taxonomy and essential oil chemotypes in sweet basil Ocimum basilicum. Phytochmistry 43(5):1033-1039

Grayson TH, Williams RJ, Wrathmell AB, Munn CB, Harris JE (1987) Effects of immunopotentiating agents on the immune response of rainbow trout, Salmo gairdneri Richardson, to ERM vaccine. J Fish Biol 31:195-202

Guardiola Abellán FA (2014) Heavy metal immunotoxicology and skin mucus in fish. PhD Thesis, Universidad de Murcia

Harikrishnan R, Balasundaram C, Heo MS (2011) Impact of plant products on innate and adaptive immune system of cultured finfish and shellfish. Aquaculture 317:1-15

Iranloye BO (2002) Effect of chronic garlic feeding on some haematological parameters. Afr J Biomed Res 5:81-82

Jang SI, Marsden MJ, Kim YG, Choi MS, Secombes CJ (1995) The effect of glycyrrhizin on rainbow trout, Oncorhynchus mykiss, leucocyte responses. J Fish Dis 18:307-315

Jeney G, Anderson DP (1993) Glucan injection of bath exposure given alone or in combination with a bacterin enhance the nonspecific defence mechanisms in rainbow trout (Oncorhynchus mykiss). Aquaculture 116(4):315-329

Jian J, Wu Z (2003) Effects of traditional Chinese medicine on nonspecific immunity and disease resistance of large yellow croaker, Pseudosciaena crocea (Richardson). Aquaculture 218:1-9

Jian J, Wu Z (2004) Influence of traditional Chinese medicine on non- specific immunity of Jiant Carp (Cyprinus carpio var. Jian). Fish Shellfish Immunol 16:185-191

Joshi SG (2000) Medicinal plants. Oxford and IBH Publishing Co. Pvt. Ltd, New Delhi, p 16

Kwapinski JB (1965) Methods of serological research. Wiley, New York, pp 5-26

Lembberkovics E, Kery A, Marczal G, Simandi B, Szoke E (1998) Phytochemical evaluation of essential oils, medicinal plants and their preparations. Acta Pharm Hung 63(3):141-149

Logambal SM, Venkatalakshmi S, Michael RD (2000) Immunostimulatory effect of leaf extract of Ocimum sanctum Linn. In Oreochromis mossambicus (Peters). Hydrobiologia 430:113-120

Magnadóttir B (2006) Innate immunity of fish (overview). Fish Shellfish Immunol 20:137-151

Malekzadeh F (1968) Antimicrobial activity of Lawsonia inermis L. Appl Microbiol 16:663-664

Maqsood S, Samoon MH, Singh P (2009) Immunomodulatory and growth promoting effect of dietary levamisole in Cyprinus carpio fingerlings against the challenge of Aeromonas hydrophila. Turk J Fish Aquat Sci 9:111-120

Maqsood S, Singh P, Samoon MH, Balange AK (2010) Effect of dietary chitosan on nonspecific immune response and growth of Cyprinus carpio challenged with Aeromonas hydrophila. Int Aquat Res 2:77-85

Markestad A, Grave K (1997) Reduction in antibacterial drug use in Norwegian fish farming due tovaccination. In: Gudding R, Lillehaug A, Midtlyng PJ, Brown F (eds) Fish vaccinology. Karger, Basel, pp 365-369

Mastoi AM, Sukumaran M, Mastoi A, Hussan A, Shaharom F, Chatterji A (2012) Differences in haematological parameters in normal, infected and immune-primed fingerlings of red tilapia (Oreochromis mossambicus $\times$ Oreochromis niloticus). Biol Forum Int J 4(1):90-97 
Mello H, Moraes JRE, Niza IG, Moraes FR, Ozório ROA, Shimada MTS, Engracia Filho JR, Claudiano GS (2013) Beneficial effects of probiotics on the intestine of juvenile Nile tilapia. Pesquisa Veterinária Brasileira 33:724-730

Mikhaeil BR, Badria FA, Maatooq GT, Amer MMA (2004) Antioxidant and immunomodulatory constituents of henna leaves. Z Naturforsch C J Biosci 59:468-476

Mirheidar H (1996) Plant education. Farhang-e-Slami Press, Tehran, p 403

Misra CK, Das BK, Mukherjee SC, Pattnaik P (2006a) Effect of multiple injections of beta-glucan on non-specific immune response and disease resistance in Labeo rohita fingerlings. Fish Shellfish Immunol 20:305-331

Misra S, Sahu NP, Pal AK, Xavier B, Kumar S, Mukherjee SC (2006b) Pre \& Post-challenge immune-haematological changes in Labeo rohita juveniles fed gelatinized or non-gelatinised carbohydrate with n-3 PUFA. Fish Shellfish Immunol 21:346-356

Modarres Mousavi Behbahani SM, Akhlaghi M, Sharifi yazdi H (2014) Phenotypic and genetic diversity of motile aeromonads isolated from diseased fish and fish farms. Iran J Vet Res 15(3):238-243

Mozaffarian V (1996) Encyclopedia of Iranian plants. FarhangMoaser Publication, Tehran (In Persian)

Nobahar Z, Gholipour-Kanani H, Kakoolaki S, Jafaryan H (2014) Effect of garlic (Allium sativum) and nettle (Urtica dioica) on growth performance and hematological parameters of beluga (Huso huso). Iran J Aquat Anim Health 1(1):63-69

Nya EJ, Austin B (2009) Use of garlic, Allium sativum, to control Aeromonas hydrophila infection in rainbow trout, Oncorhynchus mykiss (Walbaum). J Fish Dis 32:963-970

Ortuno J, Cuesta A, Rodriguez A, Esteban MA, Meseguer J (2002) Oral administration of yeast (Saccharomyces cerevisiae) enhances the cellular innate immune response of gilthead seabream (Sparus aurata L.). Vet Immunol Immunopathol 85:41-50

Prakash D, Suri S, Upadhyay G, Singh BN (2007) Total phenol, antioxidant and free radical scavenging activities of some medicinal plants. Int J Food Sci Nutr 58(1):18-28

Pratheepa V, Ramesh S, Sukumaran N (2010) Immunomodulatory effect of Aegle marmelos leaf extract on freshwater fish Cyprinus carpio infected by bacterial pathogen Aeromonas hydrophila. Pharma Biol 48(11):1224-1239

Punitha SMJ, Bab MM, Sivara V, Shankar VS, Dhas SA, Mahesh TC et al (2008) Immunostimulating influence of herbal biomedicines on nonspecific immunity in Grouper Epinephelus tauvina juvenile against Vibrio harveyi infection. Aquac Int 16:511-523

Raa J, Roestad G, Engstad RE, Robertsen B (1992) The use of immunostimulants to increase resistance of aquatic organism to microbial infections. In: Shariff IM, Subasinghe RP, Arthur JR (eds) Diseases in Asian aquaculture. Health Fish Section, Asian Fisheries Society, Manila, pp 39-50

Rao YV, Das BK, Jyotyrmayee P, Chakrabarti R (2006) Effect of Achyranthes aspera on the immunity and survival of Labeo rohita infected with Aeromonas hydrophila. Fish Shellfish Immunol 20:263-273

Rechinger KH (1968) Flora Iranic. Akademische Druck-u Verlagsanstalt Graz 51:1-2

Revertera M, Bontemps N, Lecchinia D, Banaigs B, Sasal P (2014) Use of plant extracts in fish aquaculture as an alternative to chemotherapy: current status and future perspectives. Aquaculture 433:50-61

Rodgers CJ, Furones MD (2009) The use of veterinary drugs and vaccines in Mediterranean aquaculture. In: Rogers C, Basurco B (eds) Antimicrobial agents in aquaculture: practice, needs and issues. CIHEAM, Zaragoza, pp 41-59 (Options Méditerranéennes: Série A. Séminaires Méditerranéens; n. 86)

Romero J, Feijoo C.G, Navarrete P (2012) Antibiotics in aquaculture-use, abuse and alternatives, health and environment in aquaculture. In: Carvalho ED, Silva RJ, David GS (eds) Health and environment in aquaculture. InTech, pp 159-198

Sahu S, Das BK, Mishra BK, Pradhan J, Sarangi N (2006) Effect of Allium satium on the immunity and survival of Labeo rohita infected with Aeromonas hydrophila. J Appl Ichthyol 22:1-6

Sahu S, Das BK, Pradhan J, Mohapatra BC, Mishra BK, Sarangi N (2007) Effect of Magnifera indica kernel as a feed additive on immunity and resistance to Aeromonas hydrophila in Labeo rohita fingerlings. Fish Shellfish Immunol 23:109-118

Sakai M (1999) Current research status of fish immune-stimulants. Aquaculture 172:63-92

Sakai M, Taniguchi K, Mamoto K, Ogawa H, Tabata M (2001) Immunostimulant effect of nucleotide isolated from yeast RNA on carp, Cyprinus carpio. J Fish Dis 24:433-438

Salehi Surmaghi MH (2010) Medicinal plants and phytotherapy, vol 1. Donyay Taghziah Press, Tehran

Sayyah M, Moaied S, Kamalinejad M (2005) Anticonvulsant activity of Heracleum persicum seed. J Ethnopharmacol 98:209-211

Schaperclaus W, Kulow H, Schreckenbach K (1991) Hematological and serological technique. In: Kothekar VS (ed.) Fish disease. 2nd ed. vol. 1. N, 56 Connaught circus, New Delhi: Gulabprimlani, Oxonian press Pvt. Ltd, pp. 71-108

Secombes CJ, Fletcher TC (1992) The role of phagocytes in the protective mechanisms of fish. Annu Rev Fish Dis 2:53-71

Sharma A, Deo AD, Riteshkumar ST, Chanu TI, Das A (2010) Effect of Withania somnifera (L. Dunal) root as a feed additive on immunological parameters and disease resistance to Aeromonas hydrophila in Labeo rohita (Hamilton) fingerlings. Fish Shellfish Immunol 29:508-512

Sihag RC, Sharma P (2012) Probiotics: the new ecofriendly alternative measures of disease control for sustainable aquaculture. J Fish Aquat Sci 7:72-103

Sivagurunathan A, Amila Meera K, Xavier BI (2011) Investigation of immunostimulant potential of Zingiber officinale and Curcuma longa in Cirrhinus mrigalla exposed to Pseudomonas aeruginosa- haematological assessment. Int J Res Ayurveda Pharma 2(2):899-904

Sivagurunathan A, Xavier Innocent B, Muthu Lakshmi S (2012) Immunomodulatory effect of dietary Nelumbo Nucifera (Lotus) in growth and haematology of Cirrhinus mrigala challenged with Pseudomonas aeruginosa. J Appl Pharma Sci 2(7):191-195

Siwicki Ak, Anderson DP (1993) Immunostimulation in fish: measuring the effects of stimulants by serological and immunological methods. Abstract. Symposium on fish immunology. Lysekil, Sweden, Nordic Society of Fish Immunology (NOFFI), Abstract 24 
Siwicki AK, Morand M, Terech-Majevska E, Niemczuk W, Kazun K, Glabsky E (1998) Influence of immunostimulant on the effectiveness of vaccines in fish: in vitro and in vivo study. J Appl Ichthyol 14:225-227

Uthayakumar V, Chandirasekar R, Sreedevi PR, Senthilkumar D, Jayakumar R, Ramasubramanian V (2014a) Immunostimulatory effect and disease resistance induced by Lawsonia inermis against Aphanomyces invadans in striped murrels (Channa striatus). Malaya J Biosci 1(4):231-241

Uthayakumar V, Senthilkumar D, Jayakumar R, Sreedevi PR, Satheeskumar P, Ramasubramanian V (2014b) Effect of Azadirachta indica leaf soluble fraction on immune response and disease resistance in Channa striatus against tropical freshwater fungal parasite Aphanomyces invadans (EUS). Glob Vet 13(3):355-364

Veerasamy R, Min LS, Mohanraj PR, Sivadasan S, Varghese C, Rajak H et al (2014) Effect of aqueous extract of Polygonum minus leaf on the immunity and survival of African catfish (Clarias gariepinus). J Coast Life Med 2(3):209-213

Wagner H, Kreher B, Jurcic K (1988) In vitro stimulation of human granulocytes and lymphocytes by pico- and femtogram quantities of cytostatic agents. Arzneimittelforschung 38:273-275

Widel M, Jedrus S, Lukaszczyk B, Raczek-Zwierzycka K, Swierniak A (2003) Radiation-induced micronucleus frequency in peripheral blood lymphocytes is correlated with normal tissue damage in patients with cervical carcinoma undergoing radiotherapy. Radiat Res 159:713-721

Wiegertjes GF, Stet RJM, Parmentier HK, Vas Muiswinkel WB (1996) Immunogenetics of disease resistance in fish: a comparable approach. Dev Comp Immunol 20:365-381

Yin G, Jeney G, Racz R, Xu P, Jun X, Jeney Z (2006) Effect of two Chinese herbs (Astragalus radix and Scutellaria radix) on non- specific immune response of tilapia, Oreochromis niloticus. Aquaculture 253:39-47

Yins G, Ardo L, Jeney Z, Xu P, Jeney G (2008) Chinese herbs (Lonicera japonica and Ganoderma lucidum) enhance non-specific immune response of tilapia, Oreochromis niloticus, and protection against Aeromonas hydrophila. Diseases in Asian Aquaculture VI. Fish Health Section, Asian Fisheries Society, Manila, pp 269-282 